\title{
Enzimatyc Kinetic Resolution of Hydroxy Oxazolines
}

\author{
Cleverson R. Princival (IC) ${ }^{\star 1}$, Alfredo R. M. de Oliveira (PQ) ${ }^{1}$, João V. Comasseto \\ $(P Q)^{2}$ and Jefferson L. Princival (PQ) ${ }^{3}$ \\ ${ }^{1}$ Departamento de Química - Universidade Federal do Paraná; ${ }^{2}$ Departamento de Química Fundamental - \\ Universidade Federal de Pernambuco; Departamento de Química Fundamental IQ-USP-SP \\ *princivalc@gmail.com
}

Keywords: Hydroxy Oxazolines, Kynetic Reolution

\section{INTRODUCTION}

Functionalized 2-oxazolines containing stereogenic centers are importants precursors in organic syntesis, particularly in the synthesies of substituted lactones. ${ }^{1}$ The enzimatic kinetic resolution is a tool widely used to obtain enriched enantiomericaly compounds. In addition, secondary alcohols are efficiently resolved by kinetic resolution. ${ }^{2}$ In the present work, we developed a synthetic route where hydroxyl 2-oxazolines were submited to kinetic resolution. This class of compounds could be used in synthesis of bioactive chiral lactones.

\section{RESULTS AND DISCUSSION}

The hydroxy 2-oxazolines 3a-c were prepared in an one pot operation. The aza-enolate 2, generated in situ by an acid-base reaction of the oxazoline 1 and $n$ - $\mathrm{BuLi}$, was condensed with aldehydes, epoxides or tosylates, in presence of an appropriate metallic salt, leading to the formation of hydroxy 2-oxazolines 3a-c in good yields. (Scheme 1).

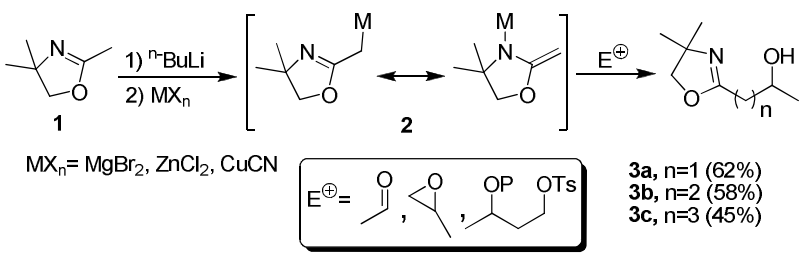

Scheme 1. Preparation of hydroxy oxazolines

The racemic hydroxy 2-oxazoline $3 \mathbf{b}(n=2)$ was submitted to the enzymatic kinetic resolution, using the enzyme CAL- ${ }^{\circledR}$ (NOVOZYME-435) and a mix of 9:1 $n$-Hexane/THF as solvent (Scheme 2).

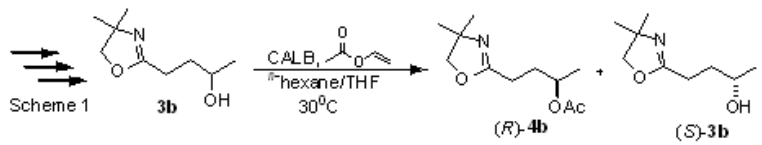

Scheme 2. Kinetic resolution of $\mathbf{3 b}$

The enantiomeric excess of acetate $\mathbf{4} \mathbf{b}$, was determinated by GC analysis. The integration showed that the acetate $\mathbf{4 b}$ has $97 \%$ of e.e. The a racemic mixture was previously synthesized and the enantiomers were separated using a chiral column. The absolute configuration of the $4 \mathrm{~b}$ was indirectly $14^{\text {th }}$ Brazilian Meeting on Organic Synthesis - 14 $4^{\text {th }}$ BMOS - September 01-05, 2011-Brasilia, Brazil determined by polarimetric analysis of the respective valerolactone $\mathbf{5}$, as the $(\boldsymbol{R})$ isomer. (Figure 1).

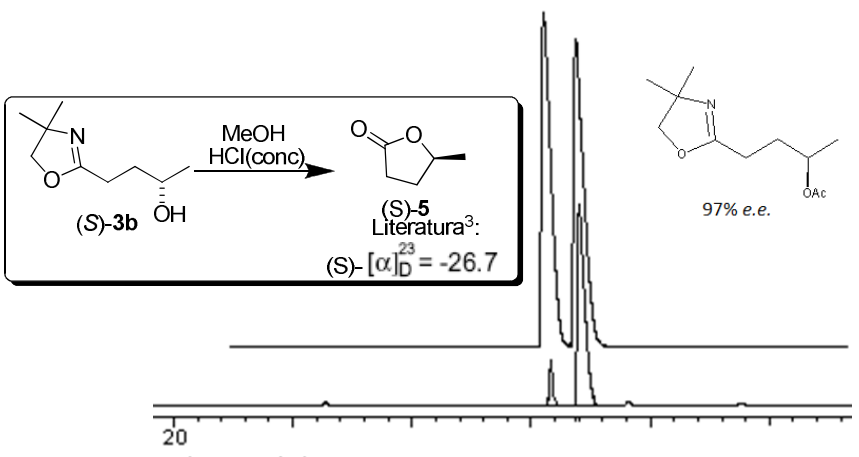

Figure 1. Chiral $\mathrm{GC}$ analysis of $\mathbf{4 b}$

Another application of these enantioenriched building blocks is the synthesis of compound 7 that is present in the blend of the pheromoneof the carpenter bee Xylocopa hirutissima ${ }^{4}$ (Figure 2).

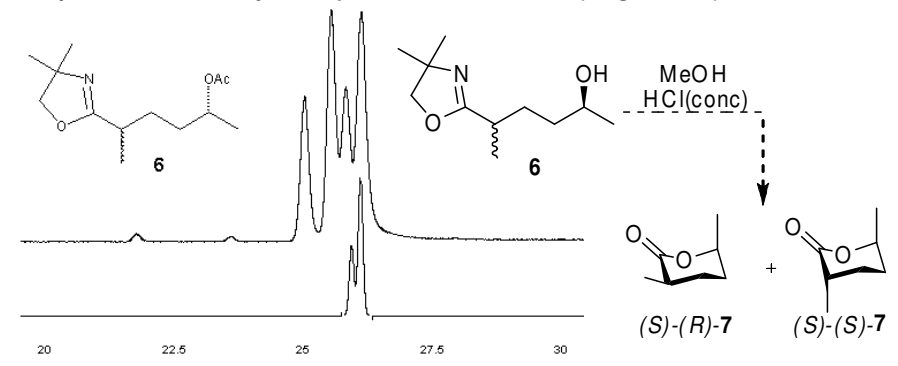

Figure 2. Chiral GC analysis of 6

\section{CONCLUSION}

Hydroxy 2-oxazolines were obtained in good isolated yields. Studies concerning the enzymatic resolution of these compounds gave good enantioselectivity and its application in the synthesis of biological active compounds are under investigation.

\section{ACKNOWLEDGEMENTS}

PRONEX-CNPq; FACEPE; INCT-INAMI; CAPES.

\section{REFERENCES}

${ }^{1}$ Curtis, M. D.; Shiu, K.; Butler, W. M. e Huffmann, J. C. J. Am. Chem. Soc. 1986, 108, 3335.

${ }^{2}$ Curtis, M. D.; Shiu, K.; Butler, W. M. e Huffmann, J. C. J. Am. Chem. Soc. 1986, 108, 3335

${ }^{3}$ Clososky, G. C.; Costa, C. E.; Missio, L. J.; Cass, Q. B.; Comasseto, J. V. Synth. Commun. 2004, 34, 817

${ }^{4}$ Weeler, J. W.; Evans, S. L.; Blum, M. S.; Velthius, H. H. V.; Camargo, J.

M. F. Tetrahedron Lett. 1976, 45, 4029. 